\title{
Mapping the Archaeology of Somaliland: Religion, Art, Script, Time, Urbanism, Trade and Empire
}

\author{
Sada Mire ${ }^{1}$
}

Published online: 14 April 2015

C The Author(s) 2015. This article is published with open access at Springerlink.com

\begin{abstract}
This paper presents the results of some of the surveys conducted to map archaeological sites of Somaliland and includes almost 100 new and previously unpublished sites. The survey work was conducted by several of Somaliland's Department of Archaeology staff, including Mohamed Ali Abdi, a Departmental survey officer, and the present author. This report is an archaeological testimony to the social complexity and cultural diversity of this region as a cultural crossroads for millennia, being strategically located on the Red Sea and Indian Ocean. However, the maps by no means exhaust the number of archaeological sites known to us in Somaliland. The region had vast Cushitic, pre-Christian and pre-Islamic Empires that at times formed part of the Himyarite and Sabaean cultures of Southern Arabia, the Aksumite Empire and early Islamic Empires of the Horn of Africa. The coastal populations were active seafarers according to Greek records as well as archaeological remains, linking to the Phoenician and Graeco-Roman worlds. They also formed part of an early global economy including the Silk Road. Islamic Empires of the Horn of Africa show an enormous wealth of long-distance trade - including material from Tang Dynasty to Ming Dynasty China - and the magnitude of some of their capitals such as the ruined town and burials of Aw-Barkhadle.
\end{abstract}

Résumé Cet article présente les résultats d'un certain nombre d'études sur la cartographie de sites archéologiques du Somaliland. Il comprend près de 100 nouveaux sites inédits et non publiés. Le travail d'enquête a été mené par plusieurs membres du Département d'Archéologie du Somaliland, sous la direction de Mohamed Ali Abdi, ainsi que par l'auteur du présent rapport. Cependant, les cartes ne sont nullement une énumération exhaustive du nombre de sites archéologiques connus au Somaliland. Ce témoignage archéologique traite de la complexité sociale et de la diversité culturelle de cette région, en tant que carrefour culturel depuis des millénaires, stratégiquement situé

ERC Researcher, Faculty of Archaeology, Leiden University

Sada Mire

s.mire@arch.leidenuniv.nl

1 Faculty of Archaeology, Leiden University, Leiden, The Netherlands 
sur la Mer Rouge et l'Océan Indien. Cette région comptait de vastes empires couchitiques pré-chrétiens et pré-islamiques, qui à certaines époques, ont fait partie des cultures himyarite et sabéenne de l'Arabie du Sud, de l'empire axoumite et de l'empire islamique de la Corne de l'Afrique. Des écrits grecs et des vestiges archéologiques ont démontré que ces populations côtières étaient des marins aguerris et qu'elles étaient également interconnectées avec les phéniciens et les gréco-romains. Elles ont aussi été intégrées très tôt à l'économie mondiale, notamment avec la Route de la Soie. Les empires islamiques de la Corne de l'Afrique ont développé de très importantes richesses, liées au commerce au long cours -y compris avec des marchandises en provenance de Chine, de la dynastie Tang à la dynastie Mingcomme en témoigne l'ampleur de certaines de leurs capitales, à l'image de la ville en ruines de Aw-Barkhadle et de ses sépultures.

Keywords Mapping - Survey · Rock art - Religion · Pastoralism - Ruined towns · Time · Trade · Islamic Empires of the Horn of Africa · Community archaeology · Somalia ·

Somaliland

\section{Background}

Now, almost five decades into the post-colonial era, archaeology is still in its infancy in Somalia and Somaliland. Earlier work that scholars such as Chittick (1969) and Brandt (1992) initiated, among others, has recently begun again through local initiatives after a fallow period. Returning to the region for the first time in 16 years, I was unaware of the 2007 work by the Ministry of Culture. I had gone to do archaeological research for my $\mathrm{PhD}$ and travelled immediately from Hargeysa to the east, to Berbera and to the Dhaymoole area (Map 1: 7 and 17), the home base of my maternal family, who made me aware of a great diversity of archaeology there including rock art and megalithic sites. I later travelled towards the south and west, crossing the Ethiopian border. During a month of exploration on my own, I located rock art sites, ruined towns and decorated stelae cemeteries, ancient Christian burials and sites with Himyaritic and Sabaean writing. I spent the most time at the site of Aw-Barkhadle in Hargeysa region, which was the basis of my $\mathrm{PhD}$ research on archaeology, art, religion, rituals and statehood.

When I returned to Hargeysa after a month's exploration, I had contact with the then Minister of Foreign Affairs, Abdulahi Dualeh, who kindly responded to an email I sent to him prior to my visit. He had endorsed the project and offered to meet me in Somaliland. He then suggested that I visit the Ministry of Culture and Tourism, which was said to be looking at various archaeological sites for tourism purposes. There, I met the newly appointed Minister, Abdirisaq Rooble Waaberi. After discussing the results of my survey, the Minister was keen to hire me to head a new archaeological department. We met with Somaliland's President at the time, Mr. Daahir Riyaale Kaahim, and handed him a report (Mire 2007b). The President spoke immediately of sites from his region of origin, Awdal, and as it happens, he had personal experience as a child, playing among the ruins of Abbasa (Map 1: 101), one of the best preserved ruined towns of Somaliland (Curle 1937), now covered with cacti which protects it from looters. The President agreed with the Minister that I should help establish this department and that a presidential decree would announce my immediate appointment. 


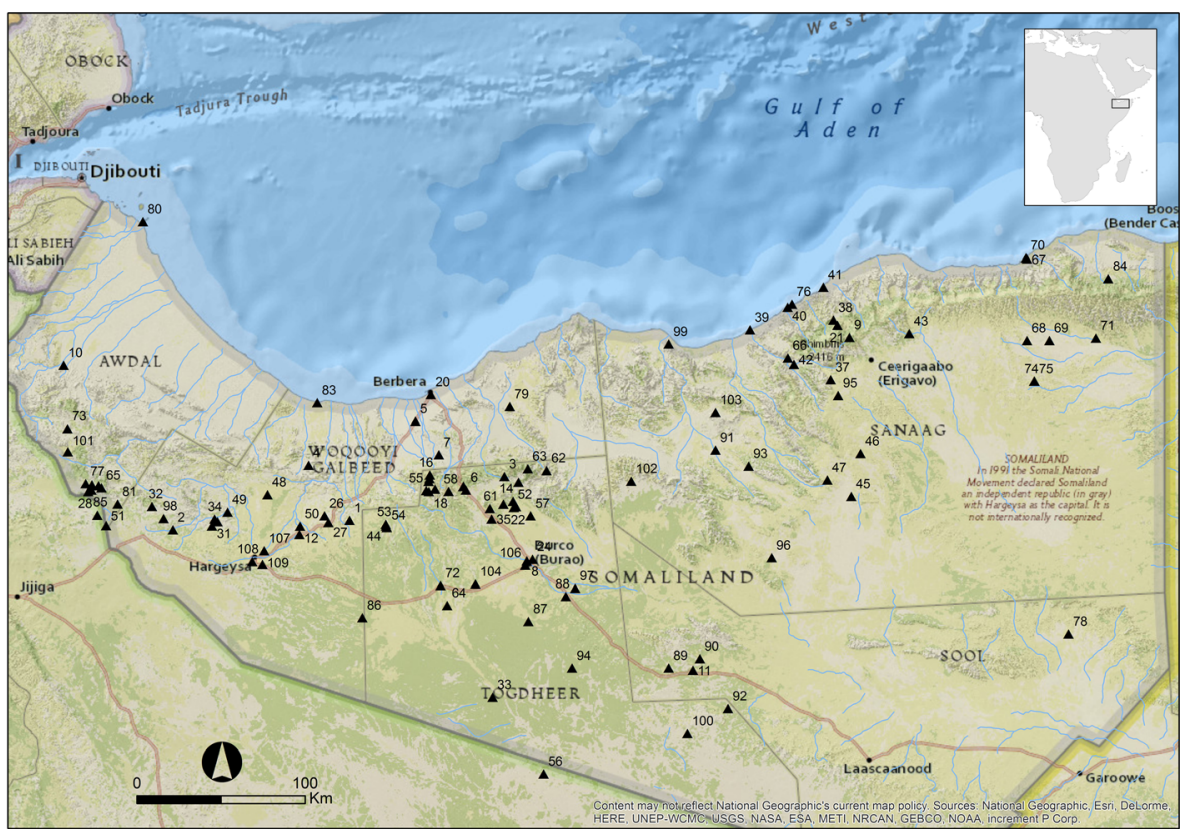

Map 1 All the sites mentioned in the table

He also said he would support it, but that we only had a couple of days to submit a budget. The budget was successful and we were able to hire dozens of new staff at the archaeological sites over 2007/2008. I also led my first official and governmental survey of three regions of Somaliland (Sanaag, Saahil and Togdheer). When I reached the town of Sanaag, I went in a shop to buy bottled water and the shopkeeper greeted me with "Do you want khat or antiquities?" This shocked me and I learned that it was a standard question in this region when an expatriate or diaspora Somali comes into the shops. Up until that moment I had not realized how severe the looting of archaeological sites had become in Somaliland. In Sanaag, I organized a number of meetings with people including a) the looters who commission illicit digging, b) the ones who dig to 'protect' before looters get to sites, and c) a diaspora Somali man (living in the Gulf), involved in illegal excavation, who proudly showed me his state-of-the-art geological tools and expensive $4 \times 4$ while never removing his expensive sunglasses and Indiana Jones-style hat. He boasted that there was material on its way to London, Milan and Paris as we spoke. I warned him that the local community might get angry when I explained to them what this business meant for their heritage; he claimed that this was his clan's land. However, a few days later when I returned to Eerigaabo, it seemed my warning had worked; the people I had been speaking with were not at all pleased with him. He was much more cooperative, and I made a report to the government which cancelled the mandate of a diaspora Somaliland heritage organization that was designed as a cover-up for the looting. However, I also realized the nightmarish situation vis-àvis protecting archaeological material in Somaliland. There was no infrastructure, no capacity building for personnel, no legal/policy framework and no financial resources 
(Mire 2011). The media had become interested in having a Somali person working in archaeology and explaining things to local people in Somali. They were keen to meet us at every town to get a summary of our findings, so that the Somaliland population were updated almost every night for the two weeks of our first mission. I started using these TV opportunities to warn people about looting sites and to empower those who were against it. This led to my doing two documentaries with Ahmed Aar, a wellknown Somali journalist, broadcast in late 2007, and other special features in 2010, 2011 and 2014, all aimed at stopping looting and destruction through archaeological awareness. Also the international media such as The Guardian, Sunday Times, BBC, $\mathrm{CNN}$, and National Geographic TV have commissioned features on our work at the Department of Archaeology. This has led to the Somali diaspora also becoming more aware of Somali heritage and archaeology, and even a few Somali students starting to study archaeology in Northern Europe and America in the last few years.

Since Somali society is very much a society in which news spreads through word of mouth, the media, especially broadcast media, has proven to be a key to getting word out about the issues at hand, both nationally and internationally (Mire 2011; van der Linde and van den Dries 2012). Sites that were previously being looted without anybody reacting are now increasingly relevant. People who were concerned about such sites got a voice, too.

However, Somaliland's Department of Archaeology continues to lack financial resources, infrastructure, trained staff, and useful laws (Mire 2008, 2011). Furthermore, and unfortunately, between 2010-2012 the Department of Archaeology was merged with the Department of Tourism, which had no budget of its own. The Department of Archaeology and Tourism brings funds to the Ministry of Finance through our tourism development efforts, yet the original budget of 2007 destined only for Archaeology is now shared by Tourism. This affects the involvement of as many local and international stakeholders as possible; continuous evaluation of this heritage should be a collective effort.

\section{An Ancient Cultural Crossroads}

A review of the literature on Somali archaeology can be found elsewhere (e.g., Mire 2007a, 2008, 2011). The importance of this region is largely due to its location at the heart of ancient long-distance trade networks, making it a cultural crossroads. What I have found in the last decade is that it is part of those landscapes inhabited by the earliest modern humans, hundreds of thousands of years ago. The Somali region was inhabited by the earliest-known pastoralists of northeast Africa, as the spectacular rock art of this region indicates, with similarities as far as the Western Desert, Libya, and Arabia (Mire 2008) (see "Rock Art and the Archaeology of Pastoralism, Ancient Writing and Symbolism of Time (ca. 3000 BCE-1500 CE)"). Its trade goods such as frankincense and myrrh were linked to temples of many ancient civilizations including Ancient Egypt, which seems to share many affinities with the region, linguistically and culturally (The "Puntite" Sites (ca. 2000 BCE-third century CE)). One readily available data source is burial traditions and art, which attest to the multi-religious heritage of this region, probably over five millennia (The Archaeology and Art of burial: Megalithic Sites (ca. 2000 BCE-1500 CE), Decorated Stelae Cemeteries (ca. 1500 BCE-1500 
CE), The "Puntite" Sites (ca. 2000 BCE-third century CE), Red Sea Sabaean/ Himyarite and Pre-Askumite Empires (ca. Ninth Century BCE-Third Century CE), The Archaeology of Ancient Christianity in the Somali Context: Burials (ca. FourthTwelfth century CE), Settlement, Trade and pre-Islamic Urban Archaeology (ca. Tenth Century BCE-Twelfth Century CE)). The region seems to have formed part of the Himyarite and Sabaean cultures (Red Sea Sabaean/Himyarite and Pre-Askumite Empires (ca. Ninth Century BCE-Third Century CE)). The Phoenician and the GraecoRoman worlds seem to have traded here too, as evidenced by material found at the ancient coastal cities, some mentioned in historic Greek records (Chittick 1975; Smith and Wright 1988). Also, the area was very much part of the pre-Axumite and Cushitic institutions of the Horn of Africa (The Archaeology and Art of burial: Megalithic Sites (ca. 2000 BCE-1500 CE), Decorated Stelae Cemeteries (ca. 1500 BCE-1500 CE), Red Sea Sabaean/Himyarite and Pre-Askumite Empires (ca. Ninth Century BCE-Third Century CE)), as well as the Aksumite Empire of the African Red Sea, that ruled even southern Arabia for a period (The Archaeology of Ancient Christianity in the Somali Context: Burials (ca. Fourth-Twelfth century CE)). The coastal populations were active seafarers, facilitating not only transmission of goods (gold, ivory, slaves, aromatic oils, animal skins, and textiles from Africa, in return for silk, glass objects, spices and Chinese porcelains, etc.) but also ideas and cultures (The Archaeology of the Islamic Empires of the Horn of Africa: Ruined Towns (ca. Sixth-Seventeenth Century CE)). Maritime archaeology is on its way but terrestrial coastal material shows that the people of this region were part of the Silk Road trade. The archaeological evidence from the Somali region shows material from Tang Dynasty to Ming Dynasty China. All these networks, trade and institutions culminated in the Islamic Medieval empires of the Horn of Africa, such as the Ifat and Awdal (Adal) states (The Archaeology of the Islamic Empires of the Horn of Africa: Ruined Towns (ca. Sixth-Seventeenth Century CE)). The above claims are all indicated by the body of past and recent archaeological discoveries in Somaliland (and Somalia) that account for more than 200 sites, many of them clusters of sites. Hopefully, proper study of these sites will substantiate and show the significance of this region for world prehistory and history.

\section{The Mapping}

The Somali region has a rich heritage of archaeological sites and seems to have enjoyed a deep longevity in settlement and use. We are here focusing on the archaeology from the Neolithic period, the last 5000-6000 years up to the twentieth century. Even so, we have only made a selection of the sites known to us from this period. Although there is some overlap with my own surveys at various times and I also visited many of the sites through governmental missions, the main surveyor of the Department of Archaeology, Mohamed Abdi Ali, reported a large part of the sites presented here; some he had found while visiting these areas and others our other regional surveyors and custodians such as Abdirahman Kahin, Ahmed Nuur Saalah and Jaamac S. Hassan passed on to him.

This article includes a table (Table 1) and four maps, the latter of which are referenced throughout by numbers within parentheses, after place-names. Map 1 includes all sites mentioned in the table; Map 2 represents all megalithic sites and decorated stelae cemeteries; Map 3 represents rock art sites and Himyarite and Sabaean 
Table 1 Table of the types of sites in Maps 1, 2, 3, and 4

\begin{tabular}{lllll}
\hline No. ID Name & $\begin{array}{l}\text { Rock Megalithic } \\
\text { Art }\end{array}$ & $\begin{array}{l}\text { Ruined } \\
\text { towns }\end{array}$ & $\begin{array}{l}\text { Deco. Anct. Inscriptions Cluster } \\
\text { stelae } \\
\text { cem. bur. }\end{array}$ \\
\hline
\end{tabular}

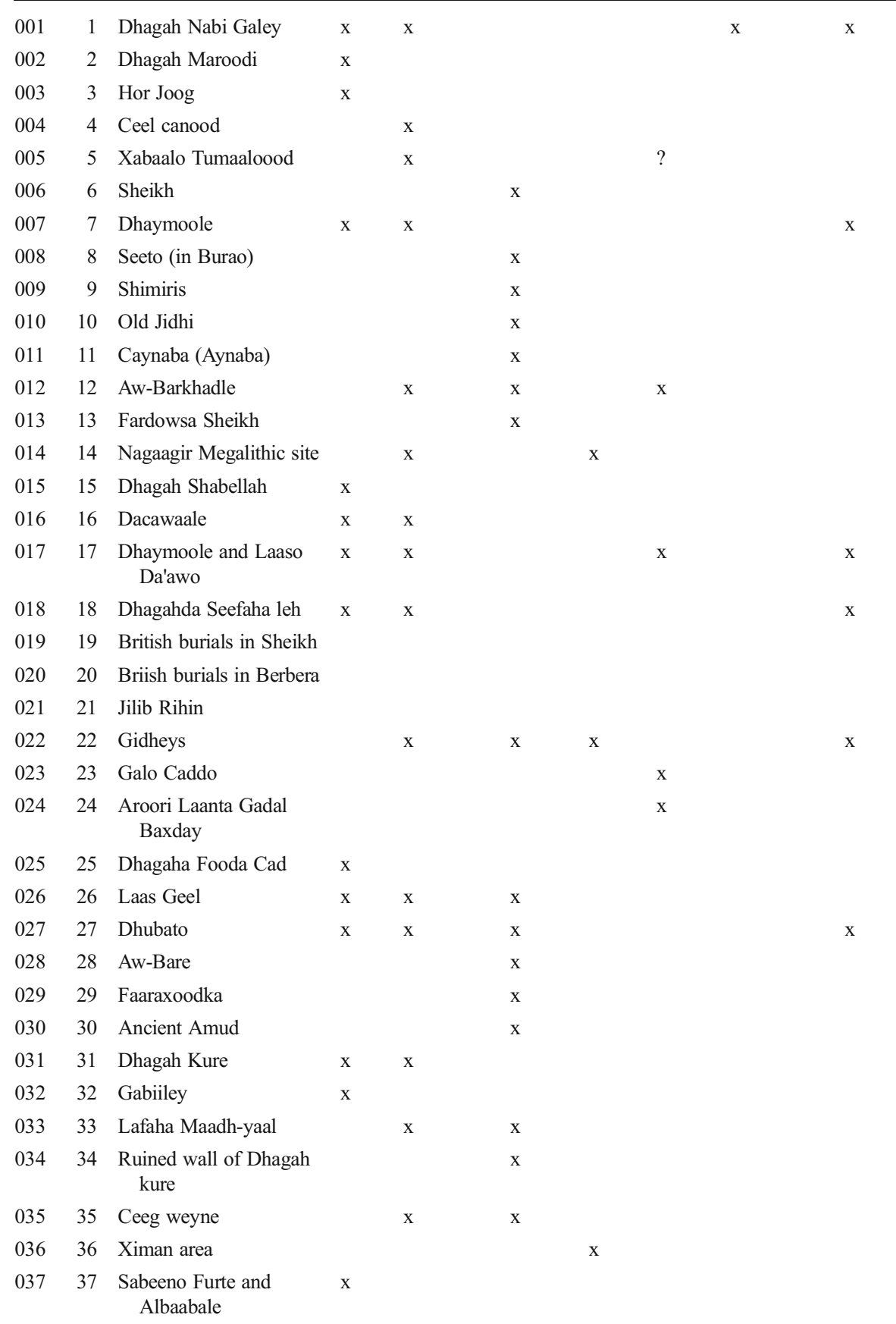


Table 1 (continued)

\begin{tabular}{lllll}
\hline No. ID Name & $\begin{array}{l}\text { Rock Megalithic } \\
\text { Art }\end{array}$ & $\begin{array}{l}\text { Ruined } \\
\text { towns }\end{array}$ & $\begin{array}{l}\text { Deco. Anct. Inscriptions Cluster } \\
\text { stelae } \\
\text { cem. bur. }\end{array}$ \\
\hline
\end{tabular}

\begin{tabular}{|c|c|c|c|c|c|c|c|c|c|}
\hline 038 & 38 & Haadh & $\mathrm{x}$ & & & & & & \\
\hline 039 & 39 & Shalcaw & & $\mathrm{x}$ & & & & $\mathrm{x}$ & \\
\hline 040 & 40 & Heis & & $\mathrm{x}$ & $\mathrm{x}$ & & & & $\mathrm{x}$ \\
\hline 041 & 41 & Maydh & & $\mathrm{x}$ & $\mathrm{x}$ & & & & \\
\hline 042 & 42 & Godmo Biyo Cas & $\mathrm{x}$ & & & & & & \\
\hline 043 & 43 & Midhishiyo shelter & & & & & & & \\
\hline 044 & 44 & Darayley and Bagan & & $\mathrm{x}$ & $\mathrm{x}$ & $\mathrm{x}$ & & & \\
\hline 045 & 45 & $\begin{array}{l}\text { Maduuna Ceel } \\
\text { Afweyn }\end{array}$ & & & $\mathrm{x}$ & & & & \\
\hline 046 & 46 & God Caanood & & & $\mathrm{x}$ & & & & \\
\hline 047 & 47 & God Hardhane & $\mathrm{x}$ & & & & & & \\
\hline 048 & 48 & Dhagahyo Gobaad & $\mathrm{x}$ & & & & & & \\
\hline 049 & 49 & Dhagah habeedaleh & $\mathrm{x}$ & & & & & & \\
\hline 050 & 50 & Sabo Cad & $\mathrm{x}$ & $\mathrm{x}$ & $\mathrm{x}$ & & & & \\
\hline 051 & 51 & Jifo-micidheer & $\mathrm{x}$ & & & & & & \\
\hline 052 & 52 & Siir & & & & $\mathrm{x}$ & & & $\mathrm{x}$ \\
\hline 053 & 53 & Qubuuraale & & & $\mathrm{x}$ & & & & \\
\hline 054 & 54 & Qalcadda & & $\mathrm{x}$ & & & & & \\
\hline 055 & 55 & Isku-dar & & & $\mathrm{x}$ & & & & \\
\hline 056 & 56 & Riyo-xidho & & $\mathrm{x}$ & & & & & \\
\hline 057 & 57 & Kal Bare & & & & & $\mathrm{x}$ & & \\
\hline 058 & 58 & Raari buul & & $\mathrm{x}$ & & & & & \\
\hline 059 & 59 & Gugux & & $\mathrm{x}$ & & & & & \\
\hline 060 & 60 & Sheikh loobogay & & & $\mathrm{x}$ & & & & \\
\hline 061 & 61 & Suuqsade (Xarago tir) & & $\mathrm{x}$ & & $\mathrm{x}$ & $\mathrm{x}$ & & \\
\hline 062 & 62 & Dhuxun of Xagal & & $\mathrm{x}$ & & & $\mathrm{x}$ & & \\
\hline 063 & 63 & Hayeeti oodan & & & & $\mathrm{x}$ & & & \\
\hline 064 & 64 & $\begin{array}{l}\text { Qar-Gebi Haqayo } \\
\text { Malaas }\end{array}$ & & $\mathrm{x}$ & & $\mathrm{x}$ & & $\mathrm{x}$ ? & \\
\hline 065 & 65 & Boorama & & & $\mathrm{x}$ & & & & \\
\hline 066 & 66 & Madigaan tomb & & & $\mathrm{x}$ & & & & \\
\hline 067 & 67 & Geel ku Qoran & $\mathrm{x}$ & & & & & & \\
\hline 068 & 68 & Haylan & & & $\mathrm{x}$ & & & & \\
\hline 069 & 69 & Sheikh Darood tomb & & & $\mathrm{x}$ & & & & \\
\hline 070 & 70 & Laas Qoray & & & $\mathrm{x}$ & & & & \\
\hline 071 & 71 & Qumbucul & & & $\mathrm{x}$ & & & & \\
\hline 072 & 72 & Oodweyne & & & $\mathrm{x}$ & & & & \\
\hline 073 & 73 & Bon & & $\mathrm{x}$ & & & & & \\
\hline 074 & 74 & Qacableh & & $\mathrm{x}$ & $\mathrm{x}$ & & & & \\
\hline 075 & 75 & Sheikh Harti tomb & & & $\mathrm{x}$ & & & & \\
\hline
\end{tabular}


Table 1 (continued)

\begin{tabular}{|c|c|c|c|c|c|c|c|c|c|}
\hline No. & ID & Name & $\begin{array}{l}\text { Rock } \\
\text { Art }\end{array}$ & Megalithic & $\begin{array}{l}\text { Ruined } \\
\text { towns }\end{array}$ & $\begin{array}{l}\text { Deco. } \\
\text { stelae } \\
\text { cem. }\end{array}$ & $\begin{array}{l}\text { Anct. } \\
\text { Christ. } \\
\text { bur. }\end{array}$ & Inscriptions & Cluster \\
\hline 076 & 76 & Salwayn & & & $\mathrm{x}$ & & & & \\
\hline 077 & 77 & Qoorgaab & & & $\mathrm{x}$ & & & & \\
\hline 078 & 78 & Taleeh & & & $\mathrm{x}$ & & & & $\mathrm{x}$ \\
\hline 079 & 79 & Dhambalin & $\mathrm{x}$ & $\mathrm{x}$ & & & & & $\mathrm{x}$ \\
\hline 080 & 80 & Zaylac & & & $\mathrm{x}$ & & & & $\mathrm{x}$ \\
\hline 081 & 81 & Cad Cad & & & $\mathrm{x}$ & & & & \\
\hline 082 & 82 & $\begin{array}{l}\text { Sheikh Dameero } \\
\text { Boobe }\end{array}$ & & & $\mathrm{x}$ & & & & \\
\hline 083 & 83 & Buulo Haar & & & $\mathrm{x}$ & & & & \\
\hline 084 & 84 & Karin Hagane & $\mathrm{x}$ & & & & & & \\
\hline 085 & 85 & Goroyo Cawl & $\mathrm{x}$ & $\mathrm{x}$ & & & & & \\
\hline 086 & 86 & $\begin{array}{l}\text { Abaadara in Haro } \\
\text { Sheikh }\end{array}$ & & & $\mathrm{x}$ & & & & \\
\hline 087 & 87 & $\begin{array}{l}\text { Balihiile, Cadaw } \\
\text { Yuurura }\end{array}$ & & & $\mathrm{x}$ & & & & \\
\hline 088 & 88 & Beer $1 \& 2$ & & & $\mathrm{x}$ & & & & \\
\hline 089 & 89 & Dhoobowayn cave & & $\mathrm{x}$ & & & & & \\
\hline 090 & 90 & Garab Cad & $\mathrm{x}$ & & & & & & \\
\hline 091 & 91 & $\begin{array}{c}\text { Dhagah Guduud } \\
\text { of Ceel Saaf }\end{array}$ & & $\mathrm{x}$ & & & & & \\
\hline 092 & 92 & $\begin{array}{c}\text { Gola-Fardood in } \\
\text { Waraabeeye }\end{array}$ & & $\mathrm{x}$ & & & & & \\
\hline 093 & 93 & Gelimaysi of Huluul & & & $\mathrm{x}$ & & & & \\
\hline 094 & 94 & Bali Abokor & & $\mathrm{x}$ & & & & & \\
\hline 095 & 95 & Badhi Gelis & & $\mathrm{x}$ & & & & & \\
\hline 096 & 96 & $\begin{array}{l}\text { Dara-yar, near } \\
\text { Garadag }\end{array}$ & & $\mathrm{x}$ & & & & & \\
\hline 097 & 97 & Taalooyin near Beer & & $\mathrm{x}$ & & & & & \\
\hline 098 & 98 & Derbiga & & $\mathrm{x}$ & & & & & \\
\hline 099 & 99 & Mura Arab & & $\mathrm{x}$ & & & & & \\
\hline 100 & 100 & Taalo dheer & & $\mathrm{x}$ & & & & & \\
\hline 101 & 101 & Abbasa & & $\mathrm{x}$ & & & & & \\
\hline 102 & 102 & Qubuuraaleh & & $\mathrm{x}$ & & & & & \\
\hline 103 & 103 & Maduuna/Xareed & & $\mathrm{x}$ & & & & & \\
\hline 104 & 104 & Kaladhac & $\mathrm{x}$ & & & & & & \\
\hline 105 & 106 & Mohamed Ali & $\mathrm{x}$ & & & & & & \\
\hline 106 & 107 & Naaso Hablood & & $\mathrm{x}$ & & & & & $\mathrm{x}$ \\
\hline 107 & 108 & Badhka & & $\mathrm{x}$ & & & & & $\mathrm{x}$ \\
\hline 108 & 109 & Mohammed Mooge & & $\mathrm{x}$ & & & & & $\mathrm{x}$ \\
\hline
\end{tabular}




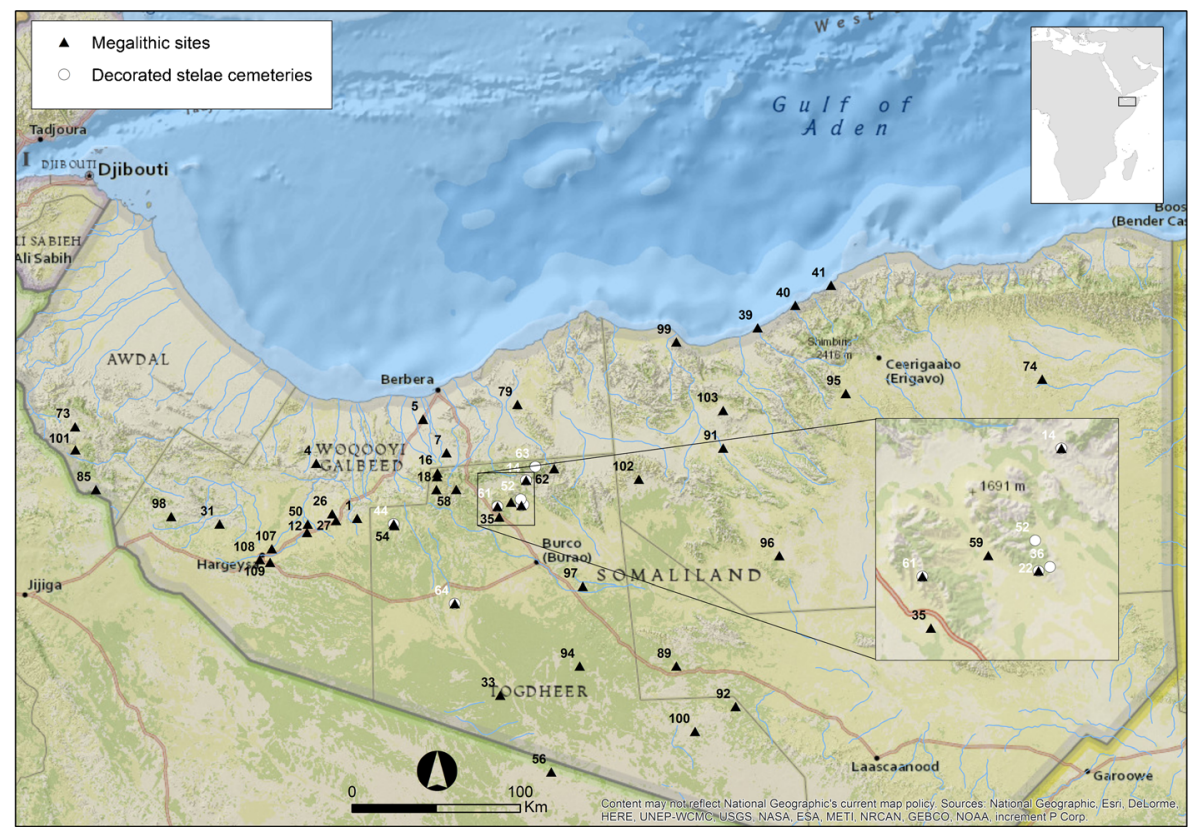

Map 2 Megalithic sites and Decorated Stelae Cemeteries

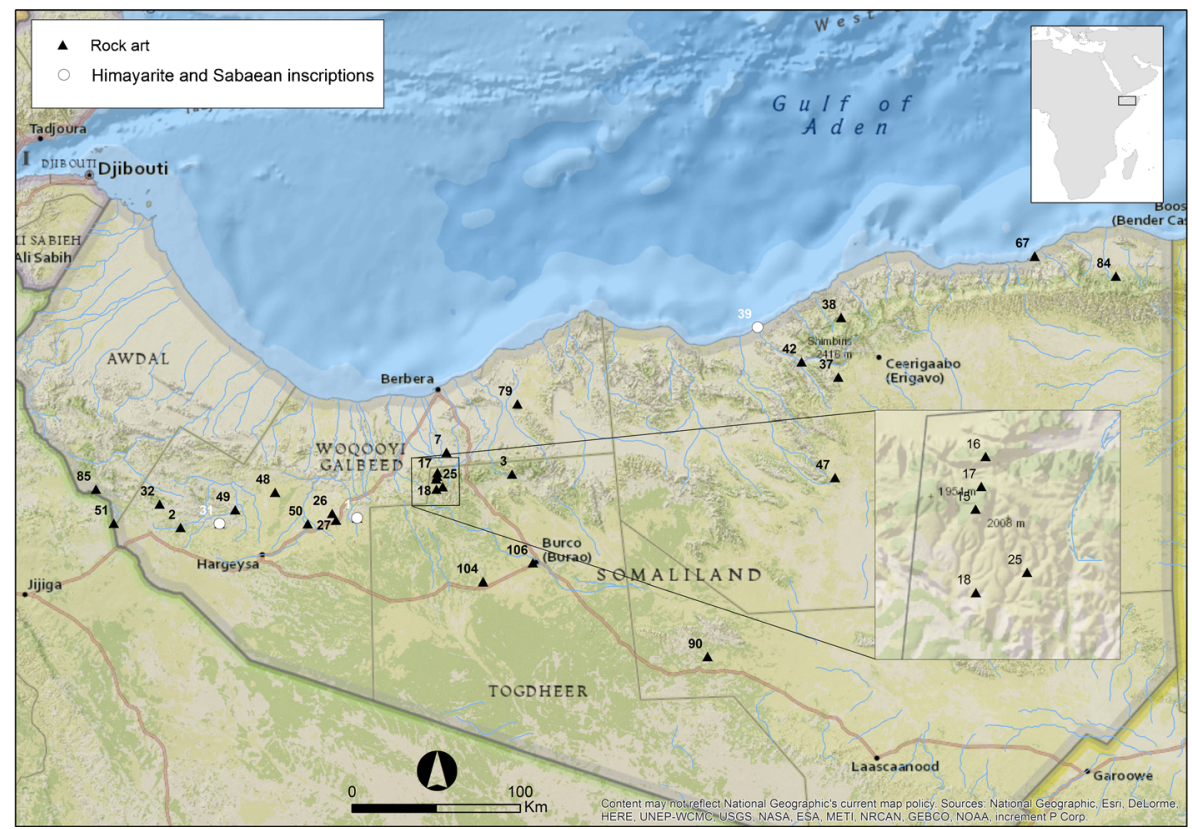

Map 3 Rock art sites and Himyarite and Sabaean inscription sites 
inscription sites; and Map 4 represents Christian burials, pre-Islamic and Islamic ruined towns. The credit information for the maps is as follows:

Format: JPEG

Resolution, 600 dpi

Made by Mads Skytte Jørgensen

Base map credits: Content may not reflect National Geographic's current map policy. Sources: National Geographic, Esri, DeLorme, HERE, UNEP-WCMC, USGS, NASA, ESA, METI, NRCAN, GEBCO, NOAA, increment P Corp.

Rivers: http://www.diva-gis.org/

\section{Rock Art and the Archaeology of Pastoralism, Ancient Writing and Symbolism of Time (ca. $3000 \mathrm{BCE}-1500 \mathrm{CE}$ )}

When Arnoldi (1984) discussed the artistic heritage of the Somali, only verbal heritage and objects were reported. However, now this should also include rock art and cave paintings, which mainly came to light in the last few decades (Brandt and Carder 1987; Gutherz et al. 2003; Mire 2008). We have over 70 sites reported to us but we now present about 30 sites in this map. The studies of rock art in this region are still in their infancy; however, the pre-civil war efforts include the work of Clark (1954), Lewis (1958) and Brandt and Carder (1987). Beyond these, not much was known until the 2000s, through the Ministry of Tourism and Culture's work in Somaliland. The rock art sites are represented in Map 3. The sites of Laas Geel (26), Dhagah Kure (31), Karin Hagane (84), Dhagah Nabi Gallay (1), Haadh (38), Jilib Rihin (21) and Dhambalin

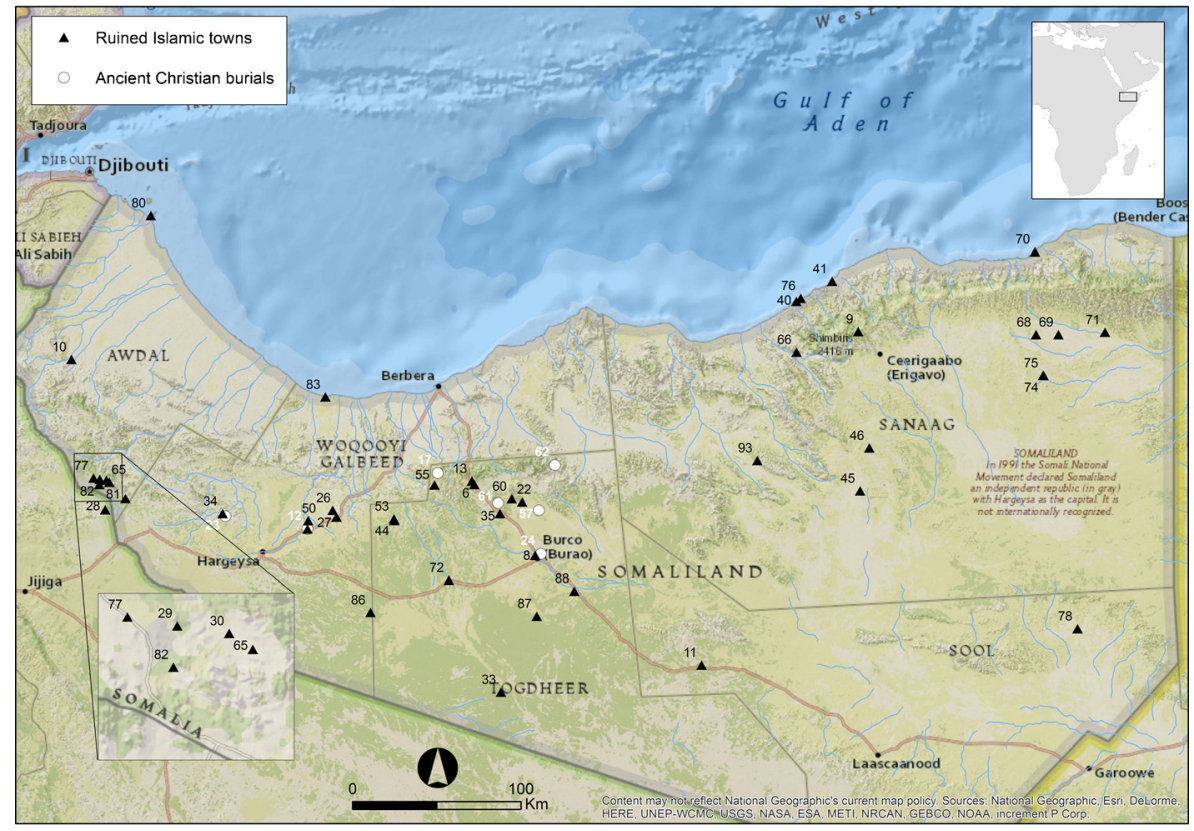

Map 4 Christian Burials and Ruined pre-Islamic and Islamic towns 
(79) depict paintings that are generally of the same style as that of the bovine rock-art sites of northeast Africa and Proto-historic, Ethio-Sabaean style (Červiček 1971, 1979). Also the petroglyph site of Dhagah Maroodi (2) is unique, since most of this type of bovine rock-art sites are painted rather than engraved. Most of the rock-art sites are on the plateau and concentrated in the natural shelters of the mountain chains, a roughly east-west belt in the middle of Somaliland. Hunt (1951) and Pallister (1963) have outlined the topography of this region. However, it will suffice to say that painted or engraved rocks are mostly of granite and limestone, but also sandstone like at Dhambalin (Mire 2008). God Hardhane, a limestone cave with pecked images, is a type of rock art found in Sanaag mostly. The unpublished site of Sabeeno Furte (37) (see Fig. 1) is also in a limestone mountain chain near Eerigaabo, in the Sanaag region. The paintings are on the side of a cliff, where the stone has been cut and smoothed, and the animal images are pecked. A considerable effort has gone into creating this art, as it is about $4-5 \mathrm{~m}$ above the bottom, where there is a spring and an underground lake below the rock. The depictions include pecked mounted horses and male figures standing alone, camels alone as well as carrying loads, caravan style. The depiction style is similar to that of the God Hardhane cave (47) (Lewis 1958), located near Ceel Afweyn, also in Sanaag region.

The rock art sites of Somaliland show that between the third and second millennium BCE, herding humpless cows (Gutherz et al. 2003), sheep and goats (Mire 2008), as well as hunting antelopes, giraffes and other wild animals, was the basis for the subsistence economy. These sites inform us about the earliest pastoralists in the Horn of Africa and food-producing societies from ca. 5000 years ago. The depictions of

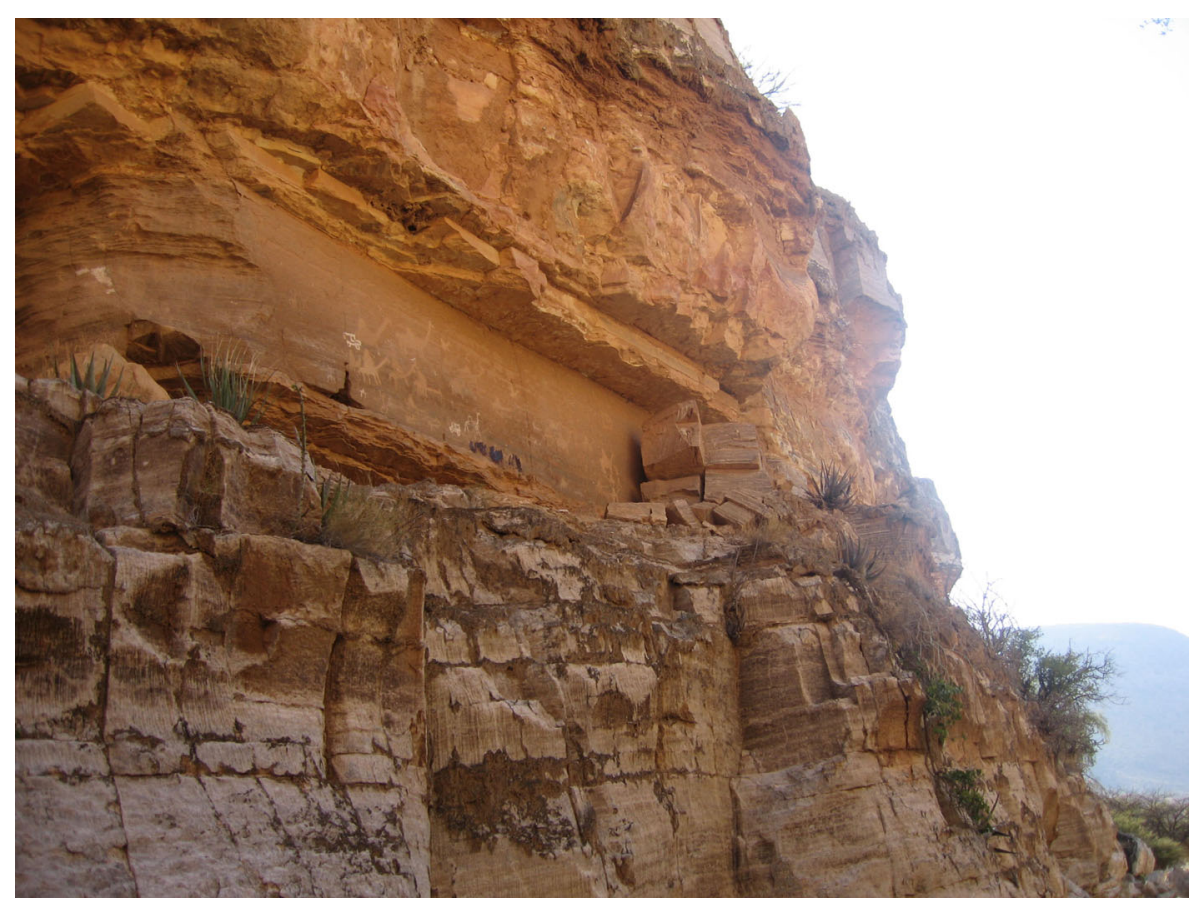

Fig. 1 Sabeeno Furte rock art site, Sanaag (Photo: by author, 2007) 
various wildlife and hunting scenes also suggest a mixed economy and much greener environment than the region offers today. The composition of the paintings suggests symbolism related to beliefs and practices (Mire 2008). The colours are rich monoand polychromes, including shades of orange, yellow, white, violet, green, red, brown, blue, and pink. Colours have mostly been sourced from local stones, some scattered at the sites. Furthermore, we also have a cross-cultural superimposition at the rock art sites of Dhambalin and Dhagah Kure. Dhambalin is the first and only site in Somali territory that depicts sheep and goats unambiguously. This site also contains a number of hunting and herding scenes that seem ritualistic, in terms of decoration of the animals and the hunting human (male) figures with dogs, and surrounded by animals including antelopes and giraffes. Animal or 'tribal' marks are also prevalent at most sites. Other animals include dogs or Canidae which accompany the human figures. In the case of Dacawale (16) in Dhaymoole where my maternal family lives, we have what appear to be lunar calendars, depicting a 28-day calendar, and crescents and full moons as well as geometric and other intricate designs and animal depictions. There is not much scope here for detail but at Dhambalin, sheep, goats and bovines are decorated and some of the decorations are similar to those at Karin Hagane and Laas Geel. Dhambalin does not have the cows typical of Dhagah Nabi Galay, Karin Hagane (Brandt and Carder 1987), Laas Geel (Gutherz et al. 2003), Jilib Rihin and Haadh (Mire 2008)—where the heads of bovines appear like a beaker-and in fact displays headless beasts. At Karin Hagane and Laas Geel types, the head is situated close to the horns, often large ones. What looks like either decoration such as a piece of garment or some other adornment (painting?) appears on the neck. These parts are combined in various colours and produce a polychrome figure. However, at all the bovine sites, the cows are depicted with full udders and clear teats.

As usual with rock-art sites, the dating remains a problem, including Laas Geel, as the only thing dating is based on is small fragments of pigment found in layers believed to date to 3500-2500 BCE. There is not a single ceramic sherd found at Laas Geel's shelter 7, the only excavated shelter, upon which the dating estimate is based. However, potential exists at Dhambalin where there are surface finds of decorated pottery as well as burials associated with the rock shelter.

Also in Dacawaale and Dhaymoole region, there are megaliths with rock art, cows and other animals painted in black and white or done as carvings. Laaso Dacawo's Dhagah Seefaha leh (18) are massive black granite stones dotted randomly, and are adjacent to what appears to be pre-Islamic burials. The stones are marked with what the local people call "swords." These "swords" are also found on similar massive black granitic stones at Goroyo Cawl (Awl) site (85), near Boorama.

We also need to understand better the rock art sites of Jifo micidheer (51), Sabo cad (50), Dhagaha habeedaleh (49), Dhagaha fooda cad (25), Dhagah Shabeeleh (15), Dhagahyo Gobaad (48) and Hor joog (3).

\section{The Archaeology and Art of Burial: Megalithic Sites (ca. 2000 BCE-1500 CE)}

David Phillipson (1998) reckons the use of stelae to mark graves was a widespread practice in northeast Africa between 5000-2000 years BCE. The Cushitic (Hamitic) 
word hawelti for standing stelae is borrowed into the Semitic languages of the Horn later. However, in the literature of the Horn of Africa, megalithic sites and cemeteries are mostly known from Ethiopia, which hosts sites such as Aksum, Tiya and Tutu Fela (Azaïs and Chambard 1931; Breuil 1934; Graziosi 1964; Joussaume 1981, 1995; Phillipson 1998). Except for cairns (araweelooyin) (Lewis 1961), no other stone architectural burial structures have been reported previously in Somali archaeology. Cairns are found all over the country and in certain areas they are aligned, as along the Red Sea coast roads between coastal Heis (Xiis) (40) and Maydh (41) in Sanaag region (see Fig. 2). However, the recent surveys have yielded countless megalithic burials and stelae cemeteries (see Map 2), some of which we present here. These are under threat of looting and digging as well as urban development, as the demand for building material increases and the heaps of stones are easy and ready in the eyes of the stone collectors/ cutters.

Somaliland has varied burial traditions, including araweelooyin (cairns), tumuli, dolmens, ganggrifts and stelae (hawelti). Many are grouped in elaborate graves such as those in Gidheys (22). At this site, there are ancient cemeteries with single carved stones as well as stelae cemeteries. It is only during Islamic times that a certain homogeneity emerged but everything before that testifies to elaborate burial practices of localized styles.

There is a tradition of carved gravestones and decorated stelae in Somaliland, which has never been reported. Curle (1937) collected some phallic, supposed gravestones in the western region of Somaliland, but published none of these. No further information accompanies them, except that they are from Somaliland. The Horn of Africa tradition of phallic gravestones (as evidenced in Tutitui and Tutu Fela) seems to have been

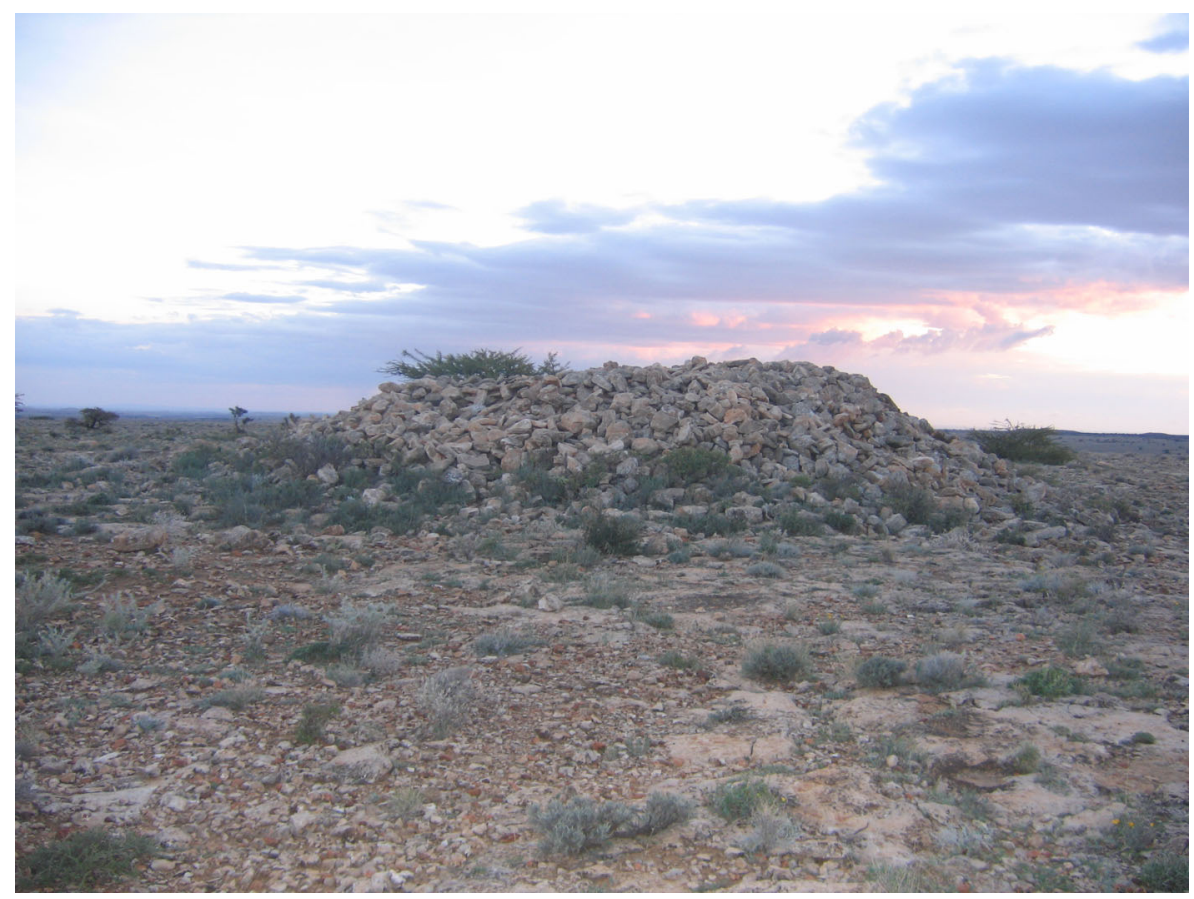

Fig. 2 Destroyed or looted cairn in Togdheer (Photo: by author, 2007) 
practiced contemporarily with Islam and, as evidence by my own study of the AwBarkhadle site (Mire 2015), perhaps in a syncretic way. Although dolmen burials are not common, they also occur at Aw-Barkhadle where I found cairns as well in 2007; however, the rapid spread of Prosopis juliflora (a type of mesquite) at the site has now hidden the dolmens completely.

When asked, locals talk about ancient traditions where some people were buried in standing or sitting positions, as well as lying down. Only excavations will yield evidence of this, but some burials are more than $2 \mathrm{~m}$ above ground and prompt such thinking, as those near Gidheys. Also, some burials are inside the trunks of big treeswhich is not too unlikely, as the belief in sacred trees was widespread, pre-Islamic and also contemporary with Islam (Mire 2015). A grave marked with a stele carrying an Orthodox cross was found in situ at Aw-Barkhadle, which confirms that Christianity was known here during pre-Islamic times or contemporary with Islam. The Somali Tumaal (blacksmiths) tribe, thought to have a Hebrew origin, are said to still visit the Xabaalo tumaalood (blacksmiths' cemeteries), $30 \mathrm{~km}$ from Berbera on the Berbera Road, for ancestral veneration rites. The Somali regions in the north were, in preIslamic times, part of the Aksumite empire. Also, gravestones marked with a Star of David are found around Dhubato (27) village in Hargeysa region.

Some of the megalithic burials in Somaliland have funerary chambers (e.g., Gidheys). However, there are great similarities with sites in Ethiopia, northern Kenya, Djibouti and Eritrea. The megalithic traditions of Somaliland could go back to Neolithic times. However, many seem to be from about the second millennium BCE up until recently, being contemporary with Islam. Round or rectangular tombs with upright stelae are common too, particularly in Saahil region and Bustanka, in Dhaymooleh area.

\section{Decorated Stelae Cemeteries (ca. 1500 BCE-1500 CE)}

As noted, there is also a Cushitic tradition of stelae erection. These are usually sacred landscapes in the Horn of Africa (Mire 2015). Decorated stelae cemeteries exist in abundance in the archaeology of Ethiopia; however, in Somali region, this has not been reported previously. However, the decoration of stelae was a widely practiced tradition in Somaliland too, as recent archaeological surveys demonstrate (see Map 2). They are concentrated in the area between Sheikh in the Saahil region and Burao in the Togdheer region. The reasons for locating these sites in these areas might be partly because of the current infrastructure, which allows access while also remaining undisturbed, but also because of the fertile plateau, which attracts human habitation in general. This section on decorated stelae includes both those considered to be from pre-Christian and pre-Islamic times. These sites include Aw-Barkhadle, Gidheys, Nagaagir (14), Hayeeti (63), Qar-Gebi Haqayo Malaas (64), Siir (52), Darayley and Bagan (44), Suuqsade (Xaragotir) (61), Ximan (36) (see Fig. 3) and many more. The grave-markers carry engravings, which include solar and geometric signs as well as schematic depictions of animals.

Most decorated stelae cemeteries are found in the Saahil and Togdheer regions. Environmentally, resources might have benefitted the Golis and Wagar mountains as well as the evergreen habitat near the plateaus of Saahil region. It is possible that regions like Hargeysa might have lost some of its ancient heritage due to rapid urban 


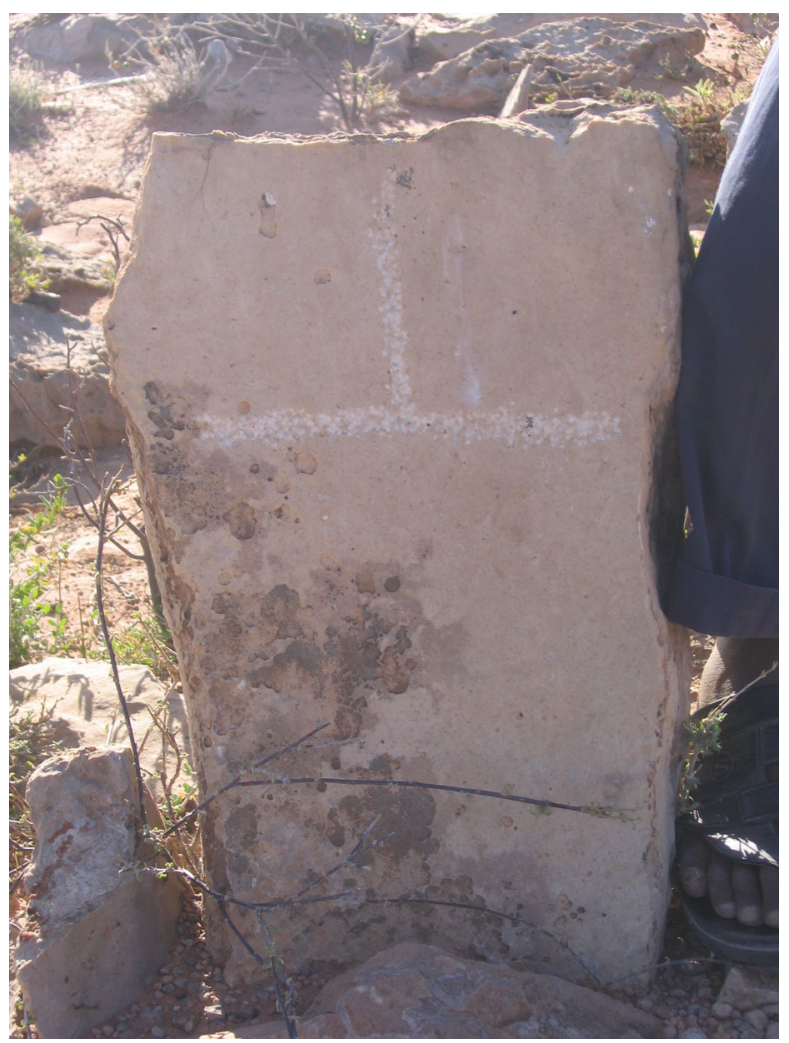

Fig. 3 Ximan decorated stelae, Toghdheer (Photo: by author, 2007)

development, at least in the last two decades. It is also possible that phallic gravemarkers have been destroyed, as these are more explicit than ancient signs. However, due to demand for illicit antiquities from Western countries like the UK and Italy, as well as the Gulf countries, this is one of the most threatened class of Somali antiquities (Mire 2011). Similar sites have been looted in Dhaanbari, near Sheikh (Mire 2011).

Ximan of Saahil region in the district of Sheikh has huge wadis surrounded by decorated stelae of about $1 \mathrm{~m}$ in height, carved with symbols including geometric patterns, which indicate Cushitic pre-Islamic cultures probably a few millennia old. The cave paintings of Dacawale contain signs that may be similar to those on grave-markers in Ximan and some other sites in the Saahil region. At Suuqsade in the district of Sheikh, there are various types of graves including some huge cairns (araweelooyin/ maguurto) and decorated stelae cemeteries. South of Suuqsade are mountains in an area known as Xaragotir, which has decorated stelae cemeteries and cruciform burials as well as huge cairns.

At the site of Hayeeti Oodan, near Berbera in the Saahil region, we have many different burials. Mohamed Abdi Ali reported a grave marked with a stele engraved with what looks to me like a crown. This could be the grave of a pre-Islamic regional priest, perhaps a Christian priest. 


\section{The "Puntite" Sites (ca. 2000 BCE-third century CE)}

In relation to the discussion of cairn sites, it must be noted that since 2012 in Somaliland, there have been reports of "Pharaonic" or "Puntite sites," which all seem to be associated with cairns (see Map 2). There is no scope in this article to discuss the Land of Punt, which is located possibly somewhere on the African side of the southern Red Sea Coast, but readers can consult the literature (e.g., Bard and Fattovich 2007; Phillips 1997; Kitchen 1993). I was asked by the Somaliland Government to investigate claims made about the existence of such objects in the summer of 2014. The Ministry of Tourism had been having problems with a man who called himself a Sheikh and claimed to have spirits working with him, digging sites. I let him take me to the sites he found with the help of these spirits (gins). Another man who works with him showed me pictures of the digging, and a film of the two of them and another man, involved with the Ministry, digging such sites. The Sheikh took me to his house in Hargeysa to show me the so-called "Pharaonic" sculptures. He proudly declared that he was selling them for up to US \$15000, and named well-known figures as his clientele. The Ministry was worried that due to the demand for illicit antiquities, there might be (re)productions of sculptures. However, the sites were former cairns that had been emptied of their stones. Usually stonecutters who are selling stones to construction companies roam the landscapes for cairn sites, as these are perfectly sized stones for building local houses. I was shown sites with alleged Pharaonic artefacts; these include the twin peaks of Naaso Hablood ("girl's breasts," 107), Maxamood Mooge (109), Hargeysa Airport area and Masalaha (108). I have previously climbed the left peak, which has shelters with stone tools. Also, there are underground caves that show ancient habitation in the area between the two peaks. The Land of Punt thus may well be the area of current-day Somalia/Somaliland. However, the current interest has triggered looting activities, as demand has increased from wealthy locals for socalled "Puntite" sculptures. The sculptures and decorated tiles claimed to be of "Puntite" origin must be examined properly along with the sites attributed to them, some of them noted in the maps herein.

\section{Red Sea Sabaean/Himyarite and Pre-Askumite Empires (ca. Ninth Century BCE-Third Century CE)}

There is an extensive and ancient relationship between the people and cultures of both sides of the Red Sea coast (Phillipson 1998). Rock art sites such as Dhagah Nabi Gallay and Dhagah Kureh include Sabaean and Himyarite writings associated with South Arabia (see Map 3). In certain contexts, they appear to have been added to the rock art later, suggesting by superimposition. In 2007, more rock art sites with Sabaean and Himyarite writings in and around Hargeysa region were found, but sadly some were bulldozed by developers, as the Ministry of Tourism could not buy the land or stop the destruction. I have also recorded a burial site with such writings in Shalcaw (39), on the Red Sea coast (see Fig. 4). Furthermore, the Qar-Gebi megalithic burials include what might be ancient writings, perhaps Himyarite and Sabaean, but it needs to be confirmed. The Pre-Aksumite cultures of current-day Ethiopia are linked with South Arabian kingdoms. The Pre-Aksumite Empire itself might have been part of, or at least culturally linked with, contemporary kingdoms in what is now the Somali- 


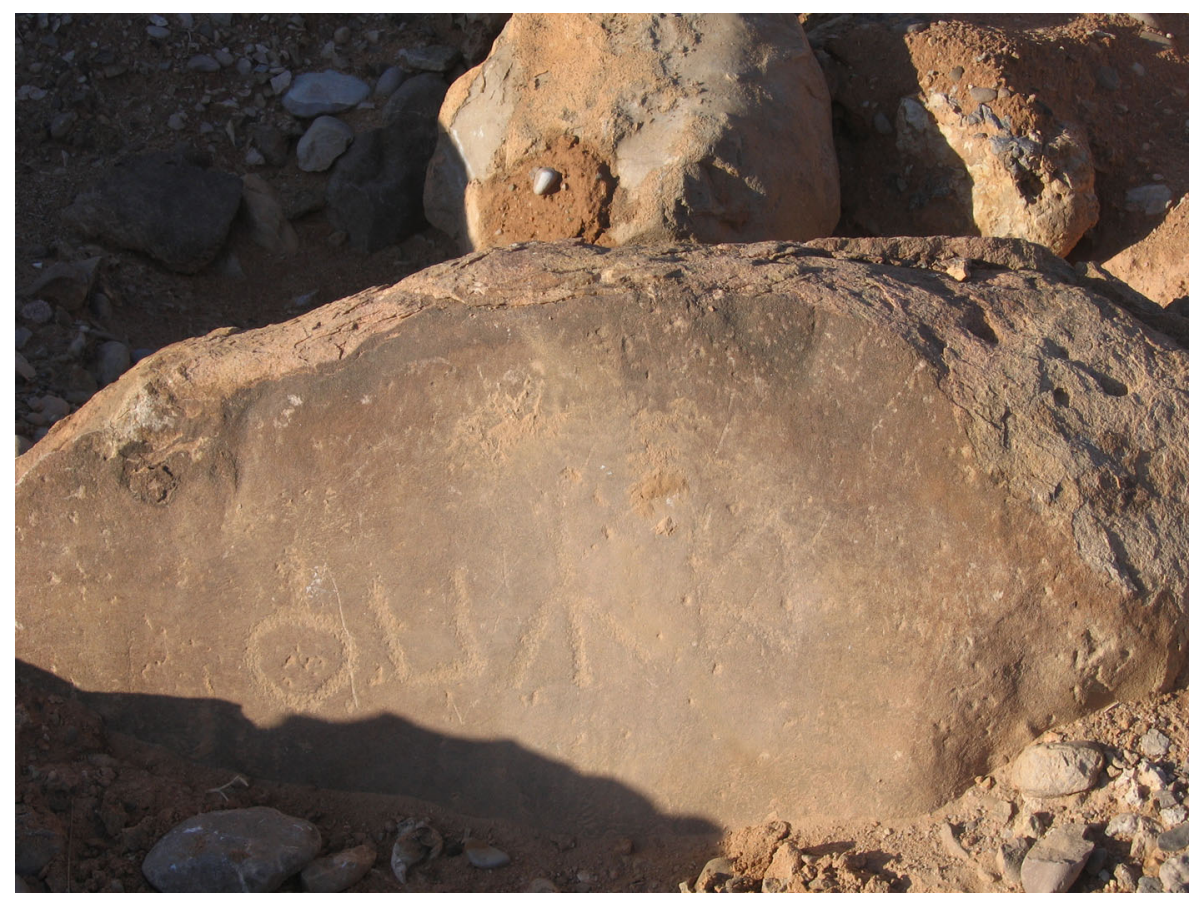

Fig. 4 Shaláw Sabaean writing, Sanaag (Photo: by author, 2007)

populated region. Not only are there links through the findings of Himyarite and Sabaean writings, but also early Christianity seems to have spread throughout the Horn, including the Somali region, as explored below. However, the burial site of Shal'aw is associated with other ancient burials in the immediate wadis in this sandy coastal landscape. The "wadi burials" are part of an ancient landscape that has been washed away by the floods and now exposed vertically, showing clear stratigraphic levels. If these burials can be rescued in time, there is a potential that we learn more about first-millennium BCE cultures of this little known Red Sea region, and associations with the Himyarite and Sabaean cultures, as well as perhaps ancient Egypt and the trade in frankincense and myrrh, still a big part of the economy in this area.

\section{The Archaeology of Ancient Christianity in the Somali Context: Burials (ca. Fourth-Twelfth century CE)}

To my knowledge, this section is the first report of ancient Christianity in Somali territory. Yet in the Horn of Africa, Christianity goes back to the first few centuries of the Current Era, the earliest such practice in sub-Saharan Africa. In Somaliland, an ancient Christian burial has been found at the pre-Islamic and Islamic site of AwBarkhadle (see Map 4). This is the first stela marked with an ancient Christian cross, probably of Byzantine appearance. Often, ancient Christian cemeteries or burials are found in what are early Islamic ruined towns. This shows that the areas that blossomed as towns under Islam were most likely also significant pre-Islamic centres. The Somali region seems to have been linked with pre-Aksumite kingdoms and South Arabian cultures as indicated by the Himyarite and Sabaean writing in the ancient burial and 
rock art contexts. Furthermore, as the pre-Aksumite culture paved the way for the Aksumite culture, it seems that the Somali region is also part of that early Christianity which presumably spread eastwards from current-day Ethiopia. Interestingly, the distribution of Christian sites falls roughly in the same area as the decorated stelae cemeteries, again another common tradition in the Horn of Africa.

The cruciform is known as laanqayr, and tombs are very common in the archaeology of Somaliland. There are also megalithic burials where the stones are arranged in a cross. The area of Dhuxun (62), in Saahil region, has many cruciform burials as well as other megalithic burials. There are many isolated, single Christian burials, massive in their design, which we have not included in this report. Dhubato in the Hargeysa region and the Saahil area have many ancient Christian burials which are aligned as a cross. Sites such as Suuqsade (Xarago tir), and Dhuxun of Xagal, Gala Caddo (23) near Dhagah Kure, Aroori (Laanta gadaal baxday) (24), and Kal Bare (57) contain ancient Christian burials. There are also finds of Christian codices in Somaliland. These seem to be written in Ethiopian languages, including Ge'es. Documentation and preservation of such ancient records is urgent. Currently, there are no measures in place by the Ministry to acquire this material due to lack of financial resources as well as awareness.

\section{Settlement, Trade and Pre-Islamic Urban Archaeology (ca. Tenth Century BCE-Twelfth Century CE)}

In terms of the first-millennium BCE settlements and towns, we know that on the Red Sea/Indian Ocean coast of Somalia there is Ras Hafun (Chittick 1975; Smith and Wright 1988). This was an important site from the third century BCE, serving as a settlement to support Graeco-Roman trade. Stern (1987) located Roman glass at Heis (Xiis), but there are also reports of Phoenician painted glass featuring female, non-African women. Also local people, while digging wells in Gabiilay (32) in the heart of western Somaliland, have located two vases, both a matte and a glazed one, the matte with figures that resemble Graeco-Roman pottery; this awaits further investigation. Greek records mention coastal fort settlements and trade with the Barbars of the Somali coast (Hourani 1995). Ancient Greek records confirm the Barbars of the coastal cities of Somali peninsula were at around $300 \mathrm{BC}$ more active seafarers than the Arabs (ibid.). We know the Greeks traded here (Stern 1987; Chittick 1975; Smith and Wright 1988).

The previously unreported ancient dry-stone towns of Ceeg Wayne (35) and Seeto (8) near Burco, Gidheys town, Darayley and Bagan in Saahil region seem to be more ancient than the early Islamic towns (see Map 4). At Ceeg Weyne, south of Burao in Togdheer region, the house foundation structures include ostrich eggshell, and the graves include what seem to be pre-Islamic as well as possibly Islamic. The site also has wadis nearby that form natural lakes (haro), according to Mohamed Ali Abdi. These sites include megalithic burial traditions that appear to be pre-Islamic such as Gidheys near Burco, an ancient town with peculiar burials. However they may either predate or are contemporary with the pre-Islamic phase of Aw-Barkhadle. 


\section{The Archaeology of the Islamic Empires of the Horn of Africa: Ruined Towns (ca. Sixth-Seventeenth Century CE)}

In his chapter on Horn of Africa's archaeology of Islam, Insoll (2003, p.45) provides background on the pre-Islamic period of the area, in which he argues that

[...] Ethiopia and the Horn maintained extensive pre-Islamic international contacts, indirectly or directly via indigenous or foreign merchants (the mechanisms are still largely unclear), with Persians (Sasanians), Arabs, Romans and Indians. Aksum and its predecessors were in contact with South Arabia and shared similar religious beliefs and other aspects of culture. Thus seen in this light Islam can be viewed not as something wholly foreign to this, the first area of Muslim contacts in sub-Saharan Africa, but as forged, in part, in the same cultural milieu.

From the archaeology outlined above, we see links between ancient Arabia, Roman and Persian cultures. A. T. Curle (1937) reported on the ruined towns of Somaliland. Later, Chittick also surveyed the northern coastal regions $(1975,1992)$. Beyond these, closer to 70 ruined towns are reported to us from local people. However, we are presenting here only about 40 sites (see Map 4). The distribution of ruined towns indicates a certain pattern such as concentrations in some areas of the country. Two particular areas stand out: the triangle between Sheikh, Hargeysa and Burao, and the area in and around Boorama in the west. The two areas confirm ancient travel routes following the east-west belt. The Red Sea ancient trade towns of Berbera and Zayla contributed to the growth of ruined towns in their hinterland. Also more inland towns to the east also blossomed due to trade via Heis (Xiis), Maydh and Laasqoray (70), which are probably also very ancient port towns, as indicated by the findings of Chittick (1975) at Ras Hafun. It is important to note that some of the earliest ruined towns in Somaliland are located in the triangular area of Sheikh-Hargeysa-Burao, as shown by the preliminary study of surface pottery collection at Fardowsa (13) (Mire forthcoming), but we are also still unsure how old the western towns in and around Boorama are. Only proper archaeological excavations will tell. However, the ruined towns of Somaliland seem to be located all over the country in every region, from east to west and along the western and southern Ethiopian borders, and along the coast of the Red Sea. Hence, the ancient towns are very much inside Somaliland. This distribution across the country challenges the notion that Arabs had outposts there, and in fact suggests that the local kingdoms of Ifat and Awdal (Adal) not only were settled people, but also were part of what might be viewed as an early Islamic Empire in the Horn of Africa. Furthermore, although archaeological excavation will, needless to say, shed light on local production as well as the scale of trade through the sea, these ruined towns confirm the wealth of their dynasties and capitals (Mire forthcoming).

The ancient Qiblatayn mosque in Zayla/Zaila/Saylac (80) is believed to align in two directions, one facing Mecca and one facing Jerusalem. Earliest Muslims were praying towards Jerusalem. According to oral history, it is one of the earliest or indeed the earliest mosque in sub-Saharan Africa. It suggests that the Prophet's family travelled through Saylac to Aksum in the mid-seventh century (Trimingham 1952, p. 44-46). The Islamic Empires of eastern Ethiopia and western Somali territory were powerful and fought bloody wars with Ethiopian Christian kingdoms (Braukämper 2002). 
Recently, the Islamization routes to the Horn have been reassessed for eastern Ethiopia (Fauvelle-Aymar and Hirsch 2004). In addition to the Qiblatayn mosque, the ruined town of Zaila includes the tomb of Sh. Ibrahim Saylici. Earliest Somali Islamic history tells of the first set of sheikhs that came to spread Islam in the Horn of Africa. The site of Qiblatayn has faced a lot of destruction through digging and exposure of foundations, without conservation or a conservation report. Only in 2007 was there a report to the UN by archaeologist George Abungu, who went there under a UNESCO assessment mission. The Ministry of Religion requested that UNESCO look at this site without prior consultation with the Ministry of Culture and Tourism; however, when Department of Archaeology was established, we tried to follow up with UNESCO regarding conservation of this important site and are still hoping to preserve it. Towns such as Zaila were capitals of the Awdal state, and are associated with, among others, Ahmed ibn Ibrahim al-Ghazi, known also as Ahmed Gurray or Gragn (gurran) ('Ahmed the left-handed').

These early Islamic Medieval ruined towns include sites at Hargeysa, Sool and Saahil, such as Aw-Barkhadle near Hargyesa (Mire 2015, forthcoming), Fardowsa in Sheikh and Caynaba (11), and Oodwayne (72). Others include those in the Sanaag region such as Maduuna (45), God Caanood (Fig. 5) in Ceel Afwayn (46) and Shimbiris, as well as ruined towns of the Awdal/Selel regions such as Cad Cad (81), Old Amuud (30), Old Jidhi (10), Derbiga (98) and Qoorgaab (77) (Fig. 6). They are testimony to the earliest states in the Horn of Africa, as they are part of the Ifat and Awdal kingdoms. A non-exhaustive and small surface collection at the ruined towns of Fardowsa has yielded Sasanian pottery of the eighth century, Yuan-dynasty Chinese ceramics of the thirteenth to fourteenth century, and Mingdynasty Chinese ceramics from the sixteenth to seventeenth century. We know that ancient

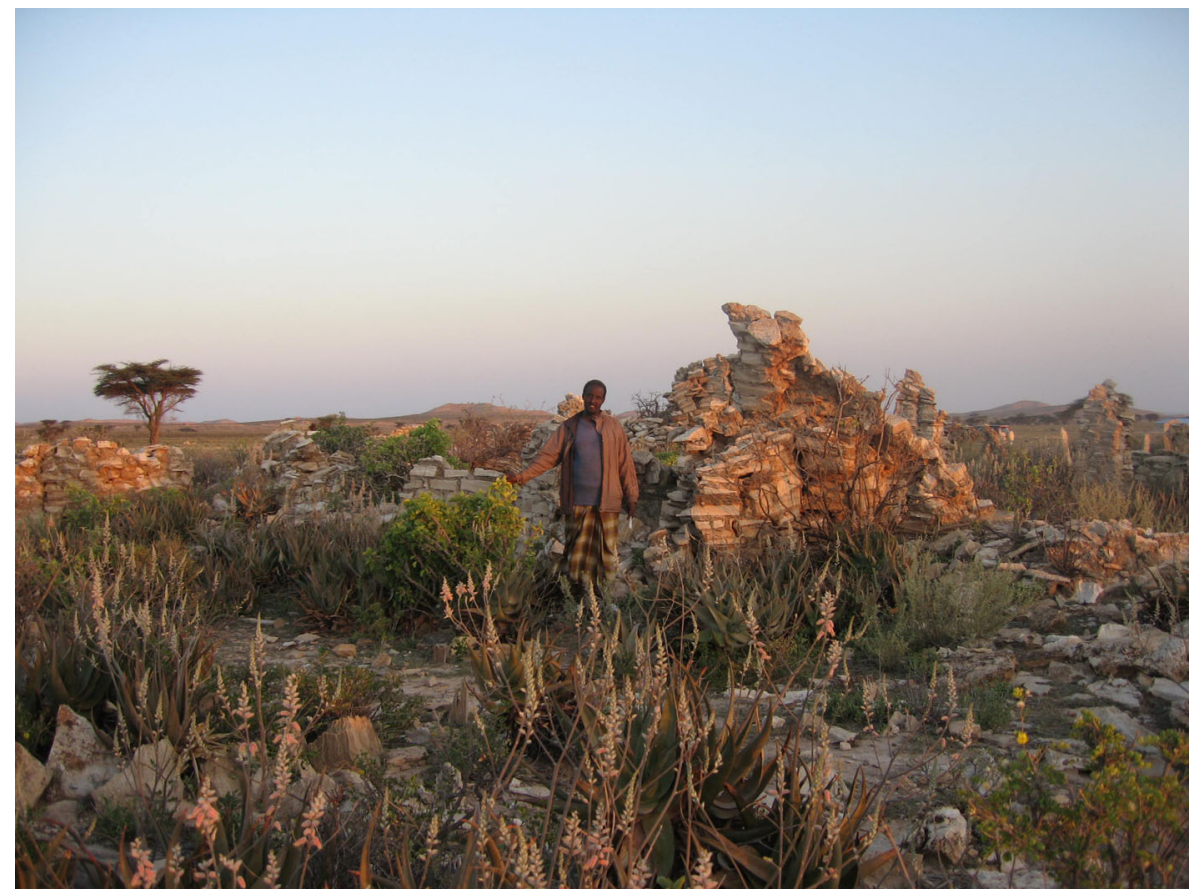

Fig. 5 God caanood ruined town, Sanaag (Photo: by author, 2007) 


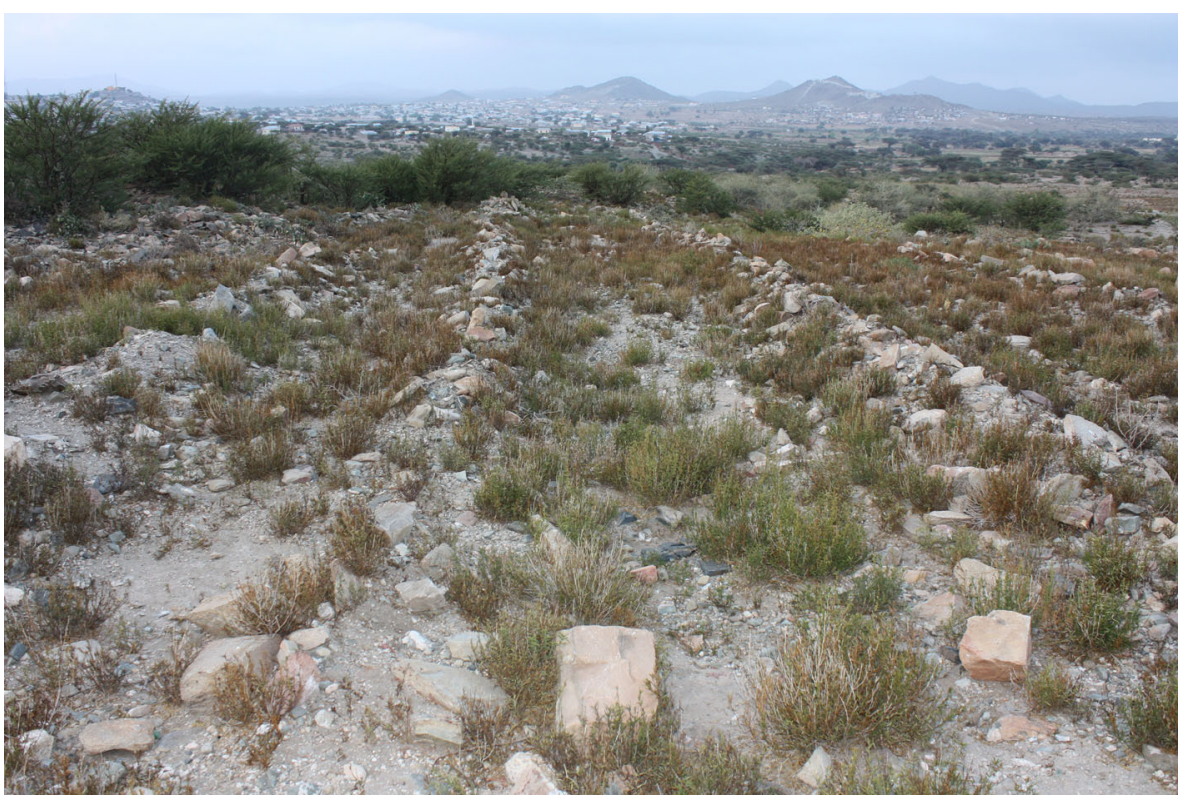

Fig. 6 Qoorgaab ruined town, Boorama (Photo: by author, 2010)

China traded with this region from the Tan dynasty (indirectly), and from Song-Yuan, China had a very detailed knowledge of places like Berbera (Pu bo li) on the Red Sea as well as other southern Somali towns such as Barawa (Bu la wa) and Mogadishu (Mu Ga Di Su) (Anshan 2012). Anshan's work outlines many ancient expeditions both from the Horn of Africa and from China as well as including a critique of Freeman-Greenville (1960), which often is cited for information about these early Chinese relations.

The Awdal and Ifat kingdoms, particularly the Walashma dynasty, justified their rule and expansion in the Horn of Africa through Islam and their direct ancestral links to Sharif Yusuf Al-Kawnayn, also known as Aw-Barkhadle (Mire forthcoming). Aw-Barkhadle is located on the eastern side of the Berbera Road that goes through current-day Aw-Barkhadle town. The site of Aw-Barkhadle includes archaeological remains, a ruined town within which the current mausoleum of Saint Aw-Barkhadle is located, as well as different types of burial traditions, including Christian, Muslim, and others of non-Islamic character such as cairns, dolmens and stelae including phallic gravestones. The leaders let themselves be buried at the Aw-Barkhadle site (Mire forthcoming). However, the site was a pre-Islamic centre, and the sacred landscape includes a mountain, trees, stones and well associated with deities, most prominently the sky God. Here, everything has been given a meaning and placed in a divine order. It connects the pre-Islamic/pre-Christian with the Islamic through myths, legends and ancestor worship.

\section{Colonial, Anti-Colonial and Nation-State Heritage: Cemeteries, Forts and "Mad Men" (Nineteenth-Twentieth Century CE)}

There are British burials, which date to the time of colonialism before 1960. I visited the burials of Berbera (20) and Sheikh (19) and found them in terrible condition; almost 
all of the stelae were destroyed or dug up and scattered about. I was told that before the 1990 war, the British cemeteries were well looked after and in fact local people used to go there to enjoy the gardens, which were nicely kept. These are today neglected, most of the stones broken off or falling down. As is the case in many urban centres in Somaliland, houses have increasingly encroached on the cemeteries, and some have disappeared under modern constructions. Such colonial heritage is disappearing in Sheikh and Berbera, which both served as power centres for the British Protectorate of Somaliland. Structures such as the Ruth Fisher Clinic still standing at the heart of Hargeysa; this building continues to symbolize the introduction of modern health care, particularly midwifery, in Somaliland.

Taleeh (78), part of a complex of forts in Sool, then a British Protectorate of Somaliland, was the headquarters and one of many defensive structures erected by Sayyid Mohamed Abdulah Hassan (see Map 4) (Douglas 1923). He was a learned man and Islamic sheikh, who started a liberation movement inspired by the jihadi legends of the sixteenth-century ruler of Awdal state, Ahmed Gurray/Gragn. Taleeh was the base for the anticolonial Dervish liberation movement led by Hassan in the late eighteenth, early twentieth century against the British. The complexity of the building and labyrinthine structures of Taleeh and other forts astonished the British, who thought that Ancient Egyptians built them, when in fact it was skilled architects and labour from the Red Sea region, motivated by colonial and anti-Christian sentiment. The British only defeated the Dervish movement by the use of Royal Air Force bombardments.

\section{Further Research and Conclusions}

Thematic, geographical and temporal surveys need to take place in Somaliland provinces; omitted from the maps presented here are Xaradhle in Sool, God Aallo and Boocane in the district of Xudun, and Laas Caanood, Caynaba and Badhwayn. Also, along the coast between Berbera and Sayla, we need additional survey, as we do along the southern Somaliland-Ethiopia border. In Togdheer, towns that we need to survey include Qoroh Weyne, Ceeldheer, Abadara, and Awliyo Koombo near Berbera, all of which need proper documentation.

As noted at the outset, I have omitted Stone Age sites and Palaeolithic history. Foremost, it was Clark who studied sites associated with Stone Age cultures (Clark 1954; Brandt 1988; Brandt et al. 1984). Sites such as Lukuud, near Aw-Barkhadle, include lithic industries and promise to be important, as do Gumburaha and the Aqalolamoodka sites near Dhubato, in Hargeysa region.

Mountain chains and wadis as well as natural lakes (haro) might shed light on movement and spread and distribution as well as subsistence economy. Wagar in Saahil includes sites such as the engraved shelter of Hor Joog, or Aarooyada (Ga'an Libaah in Saahil). The mountains of Shimbiris and Daalo in Sanaag region host many archaeological sites, also being part the ancient incense trade. The road to be built between Burco and Ceerigaabo will facilitate travel and survey, but will probably contribute to more looting. An important problem in Somaliland is that development leads to further vulnerability of archaeological heritage. Hence, there is great need for more responsible development. Currently, there is no requirement for environmental impact assessment, nor are there protective heritage laws. 
The region of current-day Somalia including Somaliland, an un-recognized de facto state in the northwestern region, has in ancient times benefited from its location as a cultural crossroad connected to many ancient land and sea routes. It led an important sea trade of its own as early as the first few centuries of first millennium BCE, as well as being a perfect stop over for many ancient ships.

The main purpose for publishing the results of this archaeological mapping in Somaliland is to make site locations known to all local stakeholders, so that they can protect this heritage collectively. As it is now, looters often know the locations better than the local communities. The majority would rather see this heritage protected and looked after for future generations, and used for tourism and educational purposes.

These archaeological sites await proper and full documentation, excavation and conservation plans. Sites such as Laas Geel, Dhagah Kure, Dhagah Nabi Galay, Saylac, Sheikh and sites around Boorama enjoy tourism due to a relatively good infrastructure; however, this has also made them more vulnerable. The rock art sites suffer degradation due to conservation problems, including erosion from wind and rain, but even the more protected rock shelters have infestations of wasps, and are sometimes inhabited by baboons who damage the walls. There is also recent graffiti, and intentional vandalism. Sadly, the painted rocks are still rocks that are utilized for building and construction. But by far the most destructive problem is looting and the aggressive, illicit trade in antiquities.

The multi-religious heritage may be important for current Somali society, which is going through turmoil politically and ideologically. The heritage, if studied and recorded properly, can help people gain insights into their own past, understand the different groups who make up Somali society who lived syncretically in the past, and perhaps better understand their present. This may be one of the most important messages of heritage and archaeology in this region.

Beyond this philosophical message, the sites, more directly, are evidence of the relevance of this region to the world. The Neolithic rock art of Somaliland informs us of the tradition of pastoralism in this region, including depictions of cattle, camels, sheep and goats. Analysis of iconography has shown that animal husbandry goes back to the third millennium BCE, at least. The map represents new rock art sites of this region, but by no means exhausts our knowledge of sites of this type. The ruined towns inform about pre-Islamic and Islamic life, trade, and interactions between local and other cultures, as well as social organization and inter-societal relationships. Decorated stelae are one of the most threatened artefacts in this region, and hold great potential for understanding not only the associated rock art, but also religious beliefs, symbolism, art, astrology, astronomy, cosmology, concepts of time and fertility. Furthermore, through thorough excavations, potential grave goods and skeletal material would have much more information to offer about the people behind these remains. We should not forget stelae with writings such as of the Himyarite and Sabaean languages as confirmed at Shal'aw too. To what extend was writing prevalent in the Somali side of this region? Where does the writing originate? We know today that the Cushitic-speaking peoples are the most numerous people in the Horn of Africa (Ehret 1995), but what is their relationship with other language groups in the region and the peoples of Southern Arabia? An ancient cultural area seems to the southern Red Sea area, specially the cultural and religious relationships between ancient Southern Arabia and the Horn of Africa. Especially 
important are the sites along the Red Sea coast, which need a thorough survey, including the Shal'aw area. Such research might shed light on the potential relationship between the ancient Horn of Africa and also Ancient Egypt. To the purpose of the latter, the current article also includes what is seen as "Puntite" sites in Somaliland. They are all near the Naaso-Hablood site, which itself has two substantial natural peaks that look like pyramids, and nurture the local idea that the ancient Egyptians were originally people from the Horn of Africa. Only further study of the sites registered as "suspected" pyramids in the table and the maps, and further survey and proper excavations at the "Puntite" sites, might shed light on so-called "Pharaonic" and "Puntite" claims.

Acknowledgments The map would have been difficult to make without the dedication, tenacity and enthusiasm of the regional and local survey staff of the Department of Archaeology. Mohamed Ali Abdi ("Mohamed dheere") helped me gather information with the help of our other surveyors, including Jaamac S. Hassan "Faas" (Toghdeer), Abdirahman Kahin (Awdal/Boorama), Ahmed Nuur Saalah (Sanaag), Muse Abdi (Dhubato/Laas Geel) and the late Ali Sa'iid Kahin. The initial draft map was kindly advised and prepared by Dr. Enrico Crema of UCL's Institute of Archaeology. Finally, Mads Skytte Jørgensen, who modified a National Geographic base map, created the maps used here. Thanks are due to my friends Marilyn Downes, who commented on the English, and Pierre Bonnard, who translated the abstract into French. I would like to thank the anonymous reviewers for their constructive comments. I would also like to thank the Editorial team of this journal. In the broader context of this study, I would like to thank everyone who has supported the establishing of the Department of Archaeology in general and our surveys in particular. I can only mention a few here: current Minister of Youth, Sports and Tourism, Ali Sa'iid Raygal; current Director General of Tourism Mr. Mahamed Hussein Dhabbeeye, Director of Tourism Mr. Ibrahim M. Diiriye; his colleagues Abdisalaan Shabeelleh and Abdiqaadir Yusuf Du'ale; the Former Minister of Culture and Tourism Mr. Abdirsaaq Rooble Waaberi, and his advisor Salebean Hassan Aalin; Former Minister of Tourism and Commerce, Mr. Abdirizaq Khlif Ahmed and a lot of support came from the Late Osman Ali Bile, former Minister of Culture and Tourism. I would like to thank the staff of the Horn Heritage Organization including its Chief Operations Officer, Mr. Abdishakur Sulub Hersi, the late Mahamoud Sheikh Idiris, who filmed some of the sites, and my mother, Ugaaso Kaahin Bulhan, who accompanied me to Sanaag region. Parts of this research were also supported financially by UCL Graduate School and the University of London through my PhD field research in 2007, and later by UNDP and IOM, the British Institute in Eastern Africa (BIEA), and the Prince Claus Foundation. However, most of the work was carried out with support mainly from local people who share our cause. I would like to thank all the kind people with whom we stayed when we settled for the night in villages and nomadic camps. Special thanks to Abdilaahi H. Iiman for continuing being a valuable support to the archaeological work in Somaliland. I also thank the current president of Somaliland H.E. Mr. Ahmed Mahamed Mahamoud "Siilanyo," First Lady Marwo Amina-Weris Sheikh M. Jirdeh and Marwo Edna Adan Ismail, Former Foreign Minister of Somaliland, and Mr. Dahir Riyaale Kaahin, the Former President of Somaliland.

Open Access This article is distributed under the terms of the Creative Commons Attribution License which permits any use, distribution, and reproduction in any medium, provided the original author(s) and the source are credited.

\section{References}

Anshan, L. (2012). A history of overseas Chinese in Africa to 1911. New York: Diasporic Africa Press.

Arnoldi, M. J. (1984). The artistic heritage of Somalia. African Arts, 17, 24-33.

Azaïs, R. P., \& Chambard, R. (1931). Cinq années de recherches archéologiques en Ethiopie. Paris: Paul Geuthner 
Bard, K. A., \& Fattovich, R. (2007). Harbor of the pharaohs to the land of Punt: Archaeological investigations at Mersa/Wadi Gawasis, Egypt, 2001-2005 (R. Fattovich). Napoli: Università degli Studi di Napoli "L'Orientale."

Brandt, S. A. (1988). Early Holocene mortuary practices and hunter-gatherer adaptations in southern Somalia. World Archaeology, 20, 40-56.

Brandt, S. A. (1992). The importance of Somalia for understanding African and world prehistory. In C. Greshekter \& H. Adam (Eds.), Proceedings of the First International Congress of Somali Studies. Atlanta: Scholars Press.

Brandt, S. A., \& Carder, N. (1987). Pastoral rock art in the Horn of Africa: Making sense of udder chaos. World Archaeology, 19(2), 194-213.

Brandt, S. A., Brook, G. A., \& Gresham, T. H. (1984). Quarternary paleoenvironments and prehistoric human occupation of northern Somalia. In T. Labahn (Ed.), Proceedings of the Second International Congress of Somali Studies, 2 (pp. 7-22). Hamburg: Helmut Buske.

Braukämper, U. (2002). Islamic history and culture in southern Ethiopia. Hamburg: Lit Verlag.

Breuil, H. (1934). Peintures rupestres préhistoriques de Harar. L'Anthropologie, 44, 473.

Červiček, P. (1971). Rock paintings of Laga Oda (Ethiopia). Paideuma, 21, 47-60.

Červiček, P. (1979). Some African affinities of Arabian rock art (pp. 5-12). XXVII: Rassegna di studi ethiopici.

Chittick, H. N. (1969). An archaeological reconnaissance of the southern Somali coast. Azania, 4, 115-130.

Chittick, H. N. (1975). An archaeological reconnaissance in the Horn: The British-Somali expedition. Azania, 11, 117-133.

Chittick, H. N. (1992). Cairns and other drystone monuments in Somali regions. In C. Greshekter \& H. Adam (Eds.), Proceedings of the First International Congress of Somali Studies. Atlanta: Scholars Press.

Clark, J. D. (1954). The prehistoric cultures of the Horn of Africa. Cambridge: Cambridge University Press.

Curle, A. T. (1937). The ruined towns of Somaliland. Antiquity, 11, 315-327.

Douglas, J. (1923). The mad mullah of Somaliland. London: Herbert Jenkins.

Ehret, C. (1995). The Eastern Horn of Africa, 1000 BC to 1400 AD: The historical root. In A. J. Ahmed (Ed.), The invention of Somalia. Lawrenceville: Red Sea Press.

Fauvelle-Aymar, F.-X., \& Hirsch, B. (2004). Muslim historical spaces in Ethiopia and the Horn of Africa: A reassessment. Northeast African Studies, 2004-2010, 11(1), 25-54.

Freeman-Greenville, G. S. P. (1960). East African coin finds and their significance. Journal of African History, 1, 31-34.

Graziosi, P. (1964). New discoveries of rock paintings in Ethiopia. Parts I \& II. Antiquity, 38, 91-98 and 187-194.

Gutherz, X., Cros, J.-P., \& Lesur, J. (2003). The discovery of new rock paintings in the Horn of Africa: The rock shelters of Las Geel, Republic of Somaliland. Journal of African Archaeology, 1(2), 227-236.

Hourani, G. F. (1995). Arab seafaring in the Indian Ocean in ancient and early medieval times. Princeton: Princeton University Press.

Hunt, J. A. (1951). A general survey of Somaliland Protectorate. London: Crown Agents.

Insoll, T. (2003). The archaeology of Islam in sub-Saharan Africa. Cambridge: Cambridge University Press. Joussaume, R. (1981). L'art rupestre de l'Ethiopie. In C. Roubet, H. J. Hugot, \& G. Souville (Eds.), Préhistoire Africaine: Mélanges offerts au doyen Lionel Balout (pp. 159-175). Paris: ADPF.

Joussaume, R. (Ed.). (1995). Tiya - L'Éthiopie des mégalithes. Du biface à l'art rupestre dans la Corne de l'Afrique. Mémorie XI. Ministère des Affaires Étrangères, Ministère de la Coopération, Ambassade de France en Èthiopie. UNESCO, UPR 311 du CNRS.

Kitchen, K. A. (1993). The land of Punt. In T. Shaw, P. Sinclaire, B. Andah, \& A. Okpoko (Eds.), The archaeology of Africa. Food, metals, and towns. London: Routledge.

Lewis, I. M. (1958). The Godhardunneh cave decorations of north-eastern Somaliland. Man, 58, 178-179.

Lewis, I. M. (1961). The so-called 'Galla graves' of northern Somaliland. Man, 61, 103-106.

Mire, S. (2007a). Preserving knowledge, not objects: A Somali perspective on heritage management and archaeological research. African Archaeological Review, 24, 49-71.

Mire, S. (2007b). The Future of Somaliland's archaeological resources. Unpublished report presented to the Ministry of Planning and to the President of Somaliland, H. E. Daahir Riyaale Kaahin.

Mire, S. (2008). The discovery of Dhambalin rock art site, Somaliland. African Archaeological Review, 25(34), 153-168.

Mire, S. (2010). Somaliland: Archaeology in a breakaway state. Current World Archaeology, 43, 26-33.

Mire, S. (2011). The knowledge-centred approach to the Somali cultural emergency and heritage development assistance in Somaliland. In F. Sulas (Guest Ed.), Special Issue: Africa's Fragile Heritages. African Archaeological Review, 29, (1), 71-91.

Mire, S. (2015). Wagar, fertility and phallic stelae: cushitic sky-god belief and the site of Saint Aw-Barkhadle in Somaliland/Somalia. African Archaeological Review 32 (1). 
Mire, S. (forthcoming). Divine fertility- material culture, rituals, sacred landscapes of cushitic horn of Africa. Walnut Creek: Left Coast Press.

Pallister, J. W. (1963). Notes on the geomorphology of the northern region of Somali Republic. The Geographical Journal, 129(2), 184-187.

Phillips, J. (1997). Punt and Aksum: Egypt and the Horn of Africa. Journal of African History, 38(3), $423-457$.

Phillipson, D. W. (1998). Ancient Ethiopia: Aksum - its antecedents and successors. London: British Museum Press.

Smith, M. C., \& Wright, H. T. (1988). The ceramics of Ras Hafun in Somalia: Notes on a classical maritime site. Azania, 23, 115-141.

Stern, M. E. (1987). Early Roman glass from Heis on the north Somali Coast. Annales du 10e Congrès pour l'Histoire du Verre (pp. 23-26). Madrid. 1985. Amsterdam: L'Association.

Trimingham, J. S. (1952). Islam in Ethiopia. London: Oxford University Press.

van der Linde, S. J., \& van den Dries, M. H. (2012). Preserving knowledge as a basic human need: On the history of European archaeological practices and the future of Somali archaeology. An interview with Sada Mire. In S. J. van der Linde, M. H. van den Dries, N. Schlanger, \& C. Slappendel (Eds.), European archaeology abroad: Global settings, comparative perspectives. Leiden: Sidestone Press. 